\title{
Trust and organisational performance: A grounded theory approach for a South African district municipality
}

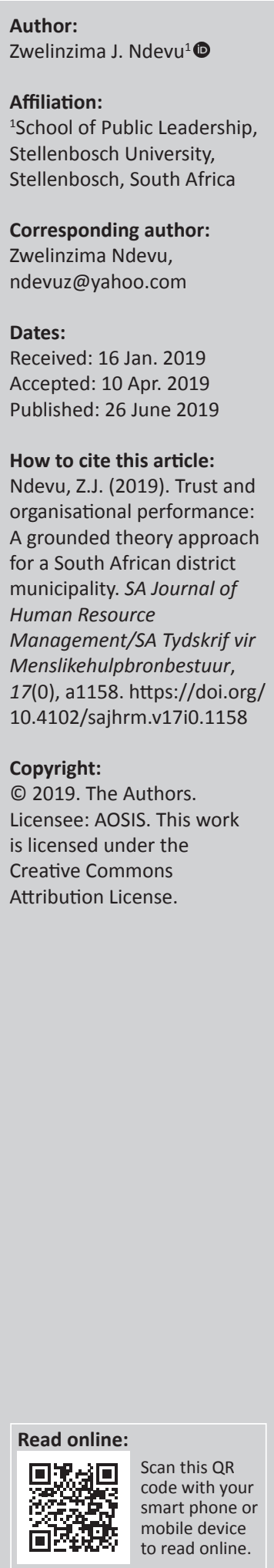

Orientation: A key role of local government in providing transparent, honest, accountable, efficient and effective service delivery to the communities they serve is determined by a number of plans, designs, actions and implementation. Trust among communities in the organisational set up is key in the success or failure of the efforts of the municipal entity and affects their individual and group performance.

Research purpose: This study examines the relationship between trust and performance within a municipal environment and its effect on service delivery.

Motivation for the study: The lack of sufficient and usable knowledge and information on the issue created the need for this research project that is an on-going effort dissecting and analysing key human resources challenges in the public sector.

Research approach/design and method: Following a brief outline of the legislation, rules and regulations that determine the responsibilities of local government in South Africa and the context of the study, the qualitative method and design of focus groups as the key instrument of data collection was identified and analysed.

Main findings: The results of the study pointed to the lack of trust among leadership and employees at all organisational levels.

Practical/managerial implications: The existence of mistrust and problems identified in the process of performance management and evaluation has negative consequences on employee performance in the municipality.

Contribution/value-add: The study findings have opened new doors to understanding key elements of organisational performance as the topic has received very scant attention in South African research literature.

Keywords: trust; organisational performance; grounded theory approach; South African District Municipality; public sector.

\section{Current context and challenges in the local government terrain}

A synopsis of key issues and challenges facing South Africa's local government terrain is important in the context of this article. Rooted in the country's first democratic constitution mainly Sections 40(1), 41(1), and 153(a) (RSA, 1996), the structure, functions, administrative systems and its key priorities towards citizens are outlined mainly in terms of budgeting and planning for development. The constitutional dictates were expanded with considerable details through the White Paper on Local Government that identified the foundations and building process of 'developmental local government' (RSA, 1998a, pp. 17-18). It set the systemic and structural foundations of organisational and strategic priorities around the Integrated Development Planning (IDP) as well as that of performance management, a fundamental cog in municipal success.

Such legislation was expanded in many ways through the introduction of the White Paper on Local Government (RSA, 1998a, pp. 92-93) that set up both the tone and priorities in the path of enhancing communities' quality of life in key areas such as job creation, safety and health, education and recreation. Inevitably such arduous tasks could only be achieved through the continuous, coordinated, cooperative strategies, decisions and actions of the country's three 
layers of government, despite the fact that this sphere of government is the foundation of citizen-based service delivery (Mopaki \& Mutono, 2016, pp. 4-5).

The values espoused in the White Paper on Local Government (RSA, 1998a, pp. 93-94) are accountability at all levels of service delivery; high priority in excellence in quality in the service outputs; emphasis on integrated development; accessibility and non-discriminatory access to all services; value for money and high quality at all levels of service delivery and affordability; and impact on local industry and commerce. Within these values and refined parameters, the municipal service excellence has to take place at highly diversified sectors of activities ranging from electricity, sanitation and water needs to produce markets and licenses, parks and tourism, libraries and security, economic and financial policing, and city planning.

The Local Government: Municipal Structures Act (117 of 1998) (RSA, 1998b) concretised the political and administrative structure of the municipal entities in terms of their types and categories, functions, divisions and powers and the strict regulations for political and administrative leaders and their expected duties and responsibilities in guaranteeing accountable, effective and efficient service delivery.

These priorities were expanded in detail in the Municipal Systems Act (32 of 2000) that underlines the key elements of the political and administrative relationships in terms of functions, processes and performance expectations on their parts, cooperative mechanisms and key responsibilities of the political and administrative leaderships (RSA, 2000a).

The Municipal Systems Act (Act 32 of 2000) deals directly with frameworks of municipal planning, resource utilisation, and organisation systems and processes, including performance management systems. It deals with strategic plans and initiatives, financial and policy frameworks and initiatives, municipal structures and priorities, intergovernmental relationships, functional and systemic guidelines and imperatives, the prioritisation of the IDP and its key guidelines in response of budgeting; public participation; spatial frameworks, disaster management initiatives; institutional priorities; communication and information channels that could lead to good governance; grassroots democratisation and sustainable community development (Gibson, 2006, p. 7; RSA, 2000a; Williams, 2006, p. 197).

The Municipal Planning and Performance Management Regulations (MPPMR) outlines the compulsory municipal 'performance management system' based on a cycle of organisational planning, measuring, monitoring, reviewing, assessing, reporting and improving through organisation and management of all employees (RSA, 2001).

Its dictates are compliant with all requirements of the Municipal Systems Act and are clear on the operational imperatives of the systems, processes, stages, operations and management at all organisational levels.

The duties, responsibilities and roles of everyone in the organisation are outlined as the processes of planning, designing and implementing measures dictated by IDP and through the stages of citizen participation.

Active public participation as the foundation of an accountable and effective municipality is also considered the key to the implementation, and expansion of local sustainable development that will cement high levels of trust to the country's intergovernmental system is the key to the priorities set by the National Development Plan (NDP).

In its honest analysis and prognosis, the NDP has outlined the key hurdles in the realisation of the goals set, despite significant progress made in a number of municipalities both in the urban and rural areas of the country. This despite the relentless challenges of expanding urbanisation, in-migration, widening of the poverty cycle, and problems and challenges that have been identified in the research undertaken by the National Planning Committee.

As expected there was also a wide array of weaknesses and challenges identified in municipalities that have been described as within the parameters of 'an enabling environment', institutional capacity and the 'macro context'. Issues in the 'enabling environment' terrain included lack of financial viability, serious infrastructure gaps, weak understanding of the powers and functions and role of the districts, lack of planning alignment among the three spheres of government, weak financial systems and political in-fighting.

Institutional capacity problems were related to the lack of political leadership, staff capacity weaknesses and gaps, high staff turnover, lack of policy understanding, factionalism and political deployments, poor values and staff attitudes, weak council performances, lack of stability, accountability and transparency and lack of legal compliance.

In the 'macro context' the issues that dominated were high unemployment, poverty and inequality, infrastructural backlogs, lack of active public participation, social ills such as drug abuse, HIV/AIDS, crime and gender-based violence, weak revenue bases, political dynamics, weak education system and the continuous stream of urbanisation and inmigration (National Public Commission, 2014, p. 438).

The fundamental challenges identified in the NDP in regard to municipalities in the NDP's 'summary section' were related to systems developments, operational guidelines at all operational levels, weak functional systems and procedures, capacity gaps, lack of long-term approach in the efforts to building local government capacity, weaknesses in provincial and national oversight and weaknesses in public mobilisation as dictated by the legislation, rules and regulations (National Public Commission, 2014, p. 438). 


\section{The significance of trust in a public sector performance environment}

An appropriate conflict-free employment relations strategy is the key to a successful organisation, and the most fundamental element of such a strategy is deeply rooted on common trust permeating all sections, divisions, leadership, management and all employees (Belle, 2014, pp. 114-115).

Organisational and state procedures and rules are significant in shaping and determining organisational imperatives, structures, systems, strategies, plans and actions of an entity, but in the final analysis the quality of existing relations depends on the levels of trust. Trust is founded and cemented mainly through the strategies, plans and actions of the leadership and higher management levels of an organisation. International research has shown conclusively that trust among key stakeholders in an organisational set up is a key element in the success of the entity. This means that trust or the lack of it within a public sector entity such as a municipality will have direct and/or indirect effects on individual or group performance (Boerner, Eisenbeiss, \& Griesser, 2007, p. 19; Hassan \& Hatmaker, 2015, pp. 1130-1131).

The latest report of the World Economic Forum in respect of world competitiveness (Schwab, 2017) indicated that South Africa has been ranked as the worst of 137 countries in the list in terms of the relationship between employer and employee. Covering both the private and the public sector the report links directly this outcome to the very low levels.

The report through its analysis identifies mistrust between employers and employees in South Africa as a phenomenon with historical roots that has been perpetrated and exacerbated by the country's lack of capacity in training, retaining and attracting talent, poor reliance on management and the existing high inequality levels, unemployment and poverty (Schwab, 2017, pp. 14-15).

The existence of an efficient and effective state and a wellfunctioning market has direct and indirect positive effects on continuous economic and social growth and development enhanced by corrupt-free competitiveness and GDP growth. On the contrary, unhealthy relations between employees and management in both sectors bear direct negative impacts on organisational performance, which bears serious threats in both sectors' ability to constructively build a more productive and equitable future for themselves and all citizens of the country as a whole (Belle, 2014, pp. 115-116; Fernandez, 2008, pp. 176-177).

The existence of a wide range of laws, rules and regulations identified above in respect of the public service systems and processes pinpoints the existence of a statutory framework that is seemingly enabling to all workplaces to adopt, plan and implement commonly agreed aims, objectives, strategies and plans in respect to all work-related aspects, collective bargaining and resolution of disputes in a collegial and legally bound manner. The existence or not of such priorities cements or destroys trust within an organisation, especially a municipality, an entity empowered legally to be the foundation of community-based efficient and effective service delivery.

The existence of trust within a municipality is instrumental in building and cementing cooperation, coordination, synergy and collective decision-making and planning, whilst mistrust is instrumental in creating and perpetrating divisions. Subsequently, the possibilities of an escalation of professional, personal, political and systemic organisational conflicts could result in the damaging of existing relationships and in the long-run organisational stability and efficiency (Caillier, 2014, pp. 220-221).

There is the perception, also confirmed in empirical studies, that widely spread mistrust can be eased out through strict and thoroughly observed reliance on existing rules and regulations that could lead to higher productivity and better performance. Such a perception is founded on the confirmed belief (or reality) that when high levels of trust exist within an organisation, employees have higher degrees of job satisfaction, motivation, self-belief, discipline and solid performance. In such a trust-driven organisational environment, the resolution of conflict is faster because of general agreements on key issues among the key elements of leadership, management and employees (Belle, 2014, pp. 112-113; Boerner et al., 2007, pp. 17-18).

Such a vision within a municipality would be the foundation of accountability, transparency, honesty and high-performance levels leading to service delivery excellence, and the development of new, fresh professional identities and relationships committed to the principles of the NDP.

The realities facing municipal employees in South Africa have been researched extensively at a number of levels, and there is no doubt that they are unique at most levels of their operational, functional and systemic existence. This is because most of them are classified as 'micro-environments' in terms of human resources realities. The municipalities that can be classified as 'mega environments' (mainly found in the urban areas) are, to a large extent, more complicated at all levels not only because of their size but also the difference of the wider spectrum of interests created by the relationships between politicians and administrators, or politicians and the private sector service providers, among other. The diversification of service delivery targets is also a key issue of difference (Van Wart, 2011).

Lack of harmonious cooperation and coordination within an organisation as a result of mistrust towards leadership, management or existing plans and decisions leads to frustration, dereliction of duty, withdrawal, absenteeism and lack of motivation. Poor work performance, ill-discipline and perpetual ignorance of duties and responsibilities have also 
been described as results of mistrust (Wright \& Pandey, 2010, pp. 77-79).

The foundation stone of trust building is employee participation summarised in the phrase 'an employee must be given a voice', pointing to collaboration, understanding and trust building. This could become a reality through the opening of communication channels, regular strategy, tactics, monitoring and evaluating meetings and socials. Such an eventuality is the exactly opposite of the 'top-down approach'. In municipalities, the latter approach is represented by the political leadership (Mayor, Speaker and senior councillor) or the administrative sector (Municipal Manager, Chief Financial Officer, etc.). The most used types of 'top-down communications' include 'leadership team briefings', electronic communication with announcements and/or instructions when need arises, or employee surveys mainly associated with employee performance cards. When the obsession with outcomes overtakes the importance of communication, information sharing and serious and honest engagement, trust tends to diminish (Vermeeren, Kuipers, \& Steijn, 2013, pp. 175-176).

Existing power relations that have become a common feature in municipalities are rooted on a number of realities such as political or administrative battles over resources, monopoly of knowledge and/or existing opportunities for corruption. They lead to a 'professional distance' between leaders, managers and employees that becomes the foundation of mistrust as employees feel alienated from existing municipal realities, knowledge, opportunities and decisions. All these are kept away from them in a situation where the leaders' and managers' authority cannot be challenged (Cho \& Lee, 2011, pp. 945-946).

It is thus the leadership's decision and prerogative to take the initiative in providing employees with the opportunities to participate actively in decision-making, to have a clear picture and understanding of decisions made by leadership and management and to see their own consultation and input on key issues regarding themselves and the communities they serve as their duty and responsibility. It is only when such an accountable, transparent, fair and collegial process of decision-making is followed that trust is built through continuous commitment that finds its organisational manifestation in voluntary cooperation, coordination and synergy that are guided by solid, fruitful and creative performance (Hassan \& Hatmaker, 2015, pp. 1128-1129).

Employee performance is directly and indirectly related to an individual or group belief that leadership and senior management involve and value employee contribution to most, if not all, aspects of the organisation. This is how trust becomes a reality (Schultz \& Van Der Walt, 2015).

Given the challenges facing human resources leaderships and practitioners throughout the organisational terrain in all societal sectors, the only organisational culture that guarantees solid and efficient employee performance is the one characterised by active participation at all levels, continuous up-skilling and development, and collective support relations at all levels involving leadership, management and all employees (Warnich, Carrell, Elbert, \& Hatfield, 2015).

It is only such an environment where core organisational aspects can be discussed, agreed upon and planned in terms of administrative, legal, regulatory, financial, budgetary requirements, risk management and effective structures, systems and processes (Hall, Pilbeam, \& Corbridge, 2013, pp. 22-23; Schuler \& Jackson, 2007).

Trust cements a culture of inclusivity, fairness and collegiality, and has been accepted as such by the principled position on the matter on behalf of the International Labour Organisation (ILO) that has described fair labour practices, equal and participatory treatment, freedom of expression, association and participation as the fundamental rights of employees and the foundation of common trust (Rainey, 2014, pp. 22-23).

The article aspires to empirically analyse the relationship between trust and organisational performance within an organisation through the utilisation of a case study of a South African district municipality.

\section{Methodological concepts and design}

The utilisation of grounded theory was the basis of the methodology used in the project. It was used to create categories from the data collected through content analysis. The analysis and dissection of data that are coded into categories led to the identification of common themes and their inter-relationships. Coding is based on the identification of keywords, phrases and codes that lead to comparisons of emerging categories of data (Corbin, Strauss, \& Strauss, 2014).

The qualitative research methodology that was utilised in this study focuses on personal views of individual with knowledge and understanding of their professional and organisational environment as well as their own interpretations of structures, systems and processes (Creswell, 2013).

The strategies behind the success of a qualitative study have been analysed by Maxwell (2010, pp. 12-13), who advocated the creation of linkages of the information gained, their impact and significance of sentences, words and narratives and their utilisation.

The data interpretation began with the arrangement of themes, content and deductions that led to the translation of meanings and inductive analysis. This process leads to specific categories as the researcher gets closer to the data, 
a fact leading to an analytical explanation from the data (Allan, 2003, pp. 7-8; Harwell, 2011, pp. 147-148).

The focus group that was utilised in this instance as the data collection tool allowed the participants to express themselves fully to semi-structured and open-ended questions directly and indirectly related to organisational and structural realities, their problems and challenges. Their feelings, knowledge, experience and attitudes were the information data (Rome, 2015).

The sample chosen to participate in the two focus groups consisted of 20 selected municipal organisation stakeholders and role players with the knowledge, expertise and direct involvement with all key aspects of the municipal environment and included five municipal councillors, five section directors, four managers and three staff working in all different sections of the establishment. Three active ward committee members also participated. These selections were principally based on the advice of Hoijer (2008, pp. 284-285) and Palys and Atchison (2012).

The substantial amount of data collected through the focus group was dissected through the process of content analysis (Bryman, 2011) of the transcribed and field notes kept by the researcher and the moderators through a careful analytical process and technique. This occurred through the data coding process that led to the themes for interpretation and analysis.

Following the end of the focus group, the transcribed document was presented to all participants for inspection and/or comment regarding its authenticity. Their position that it was a true reflection of what transpired in the group serves a guarantee of the project's reliability.

\section{Ethical considerations}

Verbal consent was obtained from all participants in the study. Confidentiality and anonymity of all respondents was guaranteed.

\section{The context}

This article utilises the experiences of staff of an Eastern Cape entity, the Joe Gqabi District Municipality (JGDM), facing over the years relatively high levels of poverty, in need of basic services such as basic infrastructure, water and sanitation.

It comprises three local municipalities, Walter Sisulu, Senqu and Elundini, with a population of 373000 people in 2016 of which $32.6 \%$ are between the ages of 0 to 14 years. It has 105000 households of which 17500 (16.48\% of the total number) are 'very formal dwelling units'. The backlog for formal dwelling units stood at 37100 in 2016 (ECSECC, 2017, p. 11).

There is a large number of people infected with HIV (44 800 in 2016), an annual increase of $2.77 \%$ since 2006 representing at the time more than $12 \%$ of the total population.
The 'official' unemployment figure in 2016 stood at 28000 , up by 4500 in 2006 (23 400 then) (ECSECC, 2017, p. 12).

Utilising the 'upper poverty line definition', the municipality in 2016 was home to 239000 people living in poverty, whilst $40.09 \%$ of the municipality's households ( $N=41200)$ had flush toilets, $21.43 \%$ of households had piped water inside the dwelling, $23.40 \%(N=24400)$ had piped water inside the yard and 9890 (9.26\% of the households) had electricity for lighting only in 2016, 75500 (70.68\%) households had electricity for lighting and other purposes and a total number of $21400(20.06 \%)$ households did not use electricity (Department of Statistics South Africa, 2016).

\section{Findings}

The questions set for discussion in the focus groups were formulated around a number of themes that dealt with a variety of issues and challenges. Trust and performance were the key factors underlying all these issues as despite the fact that all participants have common aims and objectives, it was hypothesised and expected that their beliefs, attitudes and opinions would differ for a number of reasons.

It was expected that the common beliefs of all participants would be in accordance with the key aims and objectives of every municipality basically the promotion of a healthy environment free of corruption, economic and social community development rooted on the unity of all political and administrative officials and the active public participation of all citizens.

After the completion of the focus groups, the documents were transcribed. The coding and categorisation were undertaken following the dictates of content analysis.

\section{Relationship between political office bearers, managers and community stakeholders}

Throughout the world and in South Africa there is the belief that politicians and administrative leadership management are key components of service delivery, hence they play a major role in planning and implementation from beginning to the end supported by the active participation of their communities.

It is known that such relationships in South Africa in particular have been the centre of many debates, especially as there has been a very comprehensive legislation, rules and regulations that determine the nature, duties and responsibilities of these positions.

The relationship between political leadership and leaders in municipalities in South Africa has been problematic for a number of reasons as empirical research has shown concretely (Mantzaris \& Pillay, 2014; Ngamlana, 2011).

The existence of a cooperative, collaborative, moral and synergetic relationship between the two can only benefit both 
the entity and the affected communities. Colluding or antagonistic relationships between the two could be proven catastrophic as they are a barrier to synergic and comprehensive initiatives at all strategic and operational levels, structures and processes (Mantzaris \& Pillay, 2014, pp. 17-18).

The focus groups in the present project produced a diversified array of opinions on the issue, the main difference being that of political leaders and administrators. Whilst the politicians were adamant that the relationship between the two was strong and cordial, the administrators described the circumstances as difficult because there were strong differences in the way fundamental issues of service delivery were approached and debated.

The administrators' position was that there was a strong belief among politicians that fundamentals of proper and legally bound administration were of a secondary nature and that the most fundamental political reality was 'service delivery'.

This was directly connected to the needs and demands of their constituencies, a reality that led to divisions, given that service delivery was needed by everyone.

The position described above meant that the most powerful of the politicians had the upper hand in convincing the municipal council that their ward or area was the municipal priority. According to the administrative respondents, the gist of the matter was that political and personal priorities were considered more important than those of 'the common good'. Such an attitude, it was believed, was detrimental to the functionality of the municipality because political ambitions were considered above the priorities and needs of the communities.

Such behaviour, the administrative staff felt, raised a number of questions in respect of collegiality, trust, understanding and cooperation as there was a strong feeling that the relationship was not equal as it should be, but one of dominance, authority and power. It was evident that it was very difficult for the leadership of the administrative sector to trust the elected leaders of communities, and this had dented accountability, transparency and effectiveness at all organisational levels as it negatively affected staff performance.

Such a position was strongly disputed by the political leaders who insisted that if they did not follow the dictates of the country's legislation they would not be elected again by the people. Their position as the guarantors of political, economic, financial and social stability meant that their political role in the oversight of the entity was the foundation of success. Their main function, they believed, was the stability and advancement of the municipality, hence the collaboration and coordination of the administrative and political leaderships were of paramount importance. It was, thus, the responsibility of the administrative sector to follow the leadership, supervision and oversight of the political leaders. This is because the political leaders had both the responsibility and the commitment to increase the levels of administrative performance at all organisational levels of the entity.

This meant that the municipal political leadership felt strongly that the most important management structure in the entity, the municipal council, was instrumental in supporting the smooth operation, planning and implementing of organisational priorities and it was up to the administrative component to plan and implement accordingly.

The evidence of lack of trust points to the perception or reality of political interference that leads to performance deficiencies that on occasions are also related to fear, intimidation, skewed instructions and the like (Mantzaris \& Pillay, 2014, p. 23).

The politicisation of the country's administrative terrain that has led to mistrust and inferior administrative performance, dysfunction and instability has been explored vividly in the final report of the then Department of Cooperative Governance and Traditional Affairs (2009). Poor political management and the lack of distinction between the administrative and political leaderships were thought to be the foundations of existing problems in many municipalities (Cameron, 2007, 2010).

\section{Participation of municipal stakeholders in the design, planning and implementation of service delivery decisions and targets}

Active participation of all municipal stakeholders, especially the communities, is a legal and regulatory requirement identified clearly in the White Paper on Transforming Public Services Delivery (the Batho Pele Paper) (RSA, 1998a).

The significance of this priority lies in the legal and social dictate that politicians and administrators are obligated to be transparent and accountable to all citizens regarding the planning and implementation of high standard service delivery after consulting with communities at all levels and phases of planning and implementing of services in the context of the Integrated Development Plans (IDPs).

These processes, followed up by assessment, monitoring and evaluation, should be done according to the principles of courtesy, transparency, integrity and open access to information. In case promised services are not delivered, obligatory comprehensive explanations to communities regarding the reasons for existing gaps and future remedies are due.

One of the key priorities, demands, duties and responsibilities of all stakeholders, mentioned above, is their direct and active participation in the IDP meetings, both in their preparatory and final stages. On this particular instance, there was an almost unanimous acceptance on the part of the 
political and administrative leadership that the key representatives of the groups ensure their attendance of these meetings.

This participation was, however, not matched by the community representatives, according to the ward committee members in the focus groups. It was stated that the communication and information channels used by the relevant municipal authorities have been over the years dysfunctional and did not follow the existing rules and regulations. This was the fault of both the political and administrative sectors of the municipality.

The key reasons provided by the ward committee members regarding their position on the issue were what they called the political dominance of the 'senior politicians', the councillors and those close to them. They were described as the dominant force at all levels of decision-making in the terrain of service delivery, utilising senior administrators and consultants close to them in planning, designing and controlling the budgets and financial issues related to local service delivery. This was the strategy planned especially by those who aspired to higher positions in the municipal environment.

The representatives of the community in the focus groups including the ward committee members made clear their position that the trust that should be a non-negotiable reality as a pre-condition for the realisation of effective and efficient service delivery was almost a rarity in the relationship among political and administrative leaders. This had led to seriously negative relations within the administrative sector and a downturn in individual professional performance as employees with different political allegiances felt obligated to 'toe the line' of their chosen politicians. It was strongly felt that such an environment was the result of open or 'hidden' nepotism and organisational and power relations.

\section{Employee engagement and satisfaction, communication skills and open channels for dialogue}

Given the organisational particularities of the municipality, it is inevitable that a wide array of functions such as external and internal auditing, solid financial management and risk management are crucial, but direct engagement communication and satisfaction are of key importance as open paths to direct dialogue.

When such processes are in place, trust among employees and leadership increases and the possible implementation of organisational changes on the part of leadership and management is accepted. Engagement and communication are in all organisational forms; the prerogative of leadership that espouses success through efforts that ensure employees' successful engagement, communication channels and appreciation at all levels. These are integral ingredients of strategic and tactical steps of planning ahead proactively (Rainey, 2014, pp. 128-129).
Employee engagement guarantees trust, loyalty and honesty, and these are strengthened by continuous and informative communication coupled with training at all organisational levels. Successful training at a number of levels, subjects and skills can be instrumental in cementing and enhancing trust, problem-solving, talent and career development, and workplace satisfaction (Belle, 2014, p. 128).

The responses to the question pinpointed a number of key issues pointing to the realities of service delivery backlogs and problematic relationships as their foundation.

Politicians and senior administrators, to a large extent, indicated that the channels of communication to all employees under their own jurisdiction were well established in all sections and operational layers. This was described by both groups of participants as a relationship combining both formal and informal channels of information and communication.

The same groups were adamant that their relationships with their communities were those of integrity and accountability and would or could not be achieved without the synergic and cooperative relationship among themselves.

However, when it came down to the relations among themselves as key actors and factors in the planning, designing and implementing the structures, systems and processes leading to effective and efficient service delivery, there were different responses.

Whilst there was a strong response on the part of the politicians who declared that their relationship with public servants was cordial, professional, transparent and accountable, such sentiments were not shared equally by the latter.

There were examples provided on their part pinpointing the lack of accountability and poor communication towards the administrative employees and communities from the senior political leadership, factional fights among different groups of councillors who on occasions were also joined by administrative employees belonging to a variety of professional ranks and efforts to manipulate tenders and other aspects of supply chain and procurement principles and interference in internal and external audits. The politicians' influence in the appointment of outside consultants was also mentioned on occasions.

The administrative leadership also mentioned the poor understanding and ability of municipal councillors to comprehend legislation rules, regulations and internal municipal documents adjusted by the ministry to help better and more efficient functionality of the entity.

It was stated that these realities have created serious problems for the municipal employees and their performance because there was uncertainty in regard to the way forward for the municipality. 
These attitudes reinforce the existence of a lack of trust of the administrative leadership towards the elected representatives.

Similar sentiments were expressed by the representatives of the ward committees. However, their criticism did not only target the elected politicians but also the administrative leadership and staff who were seen not only as victims of political factionalism, but also as integral part of it. This was also described as a reason that the various administrative systems were not as functional as they should be. The ward committee member's position was that the tension among the groups had serious negative effects on performance evident in both sides.

The ward committee members also raised the issue of the role of the regional secretary of the African National Congress, the majority party in the municipality, and his influence in employment of staff, redeployment of party members to a wide variety of positions and the repercussions of such actions for both the municipality and the party. It was strongly felt that such moves and the appointment of incompetent and occasionally corrupt cadres created serious problems and challenges both for the party and the municipality. Such moves, it was believed, eroded trust, widened contractions and created a seriously disturbed group of employees from the top to the bottom of the organisational pyramid.

\section{Trust, performance, job evaluation and performance management}

The legislation rules and regulations in regard to performance dynamics and imperatives for all government layers in South Africa provide comprehensive guidelines dictating the principles of implementation of a performance management system for municipalities in terms of targets, monitoring, reviewing of both political and administrative sections of the entity, as well as indicators. These are to appear in an annual performance report, and are audited by the Auditor General. The legislation states clearly that community involvement in setting up indicators, targets and review is important (RSA, 2000b).

The MPPMR (RSA, 2001) provides regulations in regard to employee contracts and performance agreement as well as methodologies and criteria for the performance system, including the issues of addressing underperformance.

Job evaluation relates to questions regarding an employee's duties, responsibilities tasks and outputs that are related to a specific job, its relationships with other jobs and functions, and their content and organisational context. Evaluation leads to job classification and enrichment that could lead to restructuring. It is the job and not the employee that is evaluated in this process, including the content and responsibilities attached as well as the organisation's plans and priorities that could be instrumental in redesigning jobs and the initiations and planning of enrichment of developmental programmes related to specialised training (Selden \& Sowa, 2011, pp. 255-256).

A performance evaluation, on the contrary, is the process and method utilised for the evaluation of the job performed by an employee. It is an integral part of official rules and regulations as well as an integral part of personal and professional development as a general, systematic and continuous assessment of performance and productivity. The performance evaluation is directly related to the designated duties and responsibilities bestowed upon the employee that are connected to established organisational objectives and criteria. In the process, weaknesses, strengths, talent, accomplishments and career development are considered (Den Hartog, Boselie, \& Paaiwe, 2004, p. 556).

There were a variety of questions in the focus groups as there was a general feeling among both political and administrative leaders that the municipality has faced both problems and challenges over the years over this issue. In the preliminary discussions, it was widely accepted by all sides of the participants that mutual trust was crucial in the successful operationalisation of the municipality's organisational strategies, tactics, planning and implementation. It was agreed that trust is the foundation of solid and fruitful performance at all organisational levels of the municipality.

Thus, each question associated with the issues is analysed accordingly.

\section{Availability of information determining objectives, measurements and targets in job and performance evaluation}

There were diverse views in response to the question whether information for determining objectives, measurements and targets is readily available to all.

Politicians were adamant that the municipal council ensured that the political oversight exercised guaranteed that all information determining objectives, measurements and targets in job and performance evaluation was available in the interests of transparency and integrity in the administrative terrain. This meant that the municipal council followed all legislative dictates, rules and regulations in response to the needs of job and performance evaluation.

The administrative leadership was in dispute of the politicians' position that the job and performance evaluation processes and systems were strictly an administration function and even the final responsibility for outcomes and outputs was planned, designed, implemented and handled by themselves. They indicated that the political oversight on the part of the council 'was just a formality' for councillors.

The representatives of the ward committees believed that the problem related to the lack of information relating and determining objectives, measurements and targets in job and performance evaluation was rooted on the relationship among 
politicians themselves as well as their different groups and the administrative leadership and employees. They opined that political factionalism has been deeply rooted over the years and was a barrier to the development of the municipality. It was this political element that dented the relationship between elected and administrative leaders and followers.

This diversity of opinions of the key role players in the municipality indicates a clear lack of trust between decisionmaking stakeholders in the state entity that in most cases leads employees feeling alienated from their organisational duties and responsibilities and has negative repercussions on their individual and collective performance (Den Hartog et al., 2004, p. 558).

\section{Final performance evaluation involvement}

The final evaluation of the instrument utilised to measure employees demands the direct and indirect involvement of the key stakeholders in the municipality.

Such involvement guarantees that the decisions taken in regard to performance and job evaluation and scoreboards take into account the realisation of strategies associated with all aspects of the fundamentals of service delivery objectives and targets as included in the IDP and the budgets which in many cases are limited because of the low revenue base of the municipality.

The political and administrative leaders participating in the group agreed that such a process faced challenges when dealing with the issues. These were basically related to lack of capacity in a number of key departments, budget and time constraints, and lack of coordination and synergy in a number of organisational entities that were crucial.

The participating administrators also identified 'politically dictated agendas' in the municipal council and nonprofessional management of the process as problems and challenges.

The above sentiments were shared by the ward committees' representatives in their totality.

Given the crucial significance of collective decisions in respect of the very professional future of employees at all professional levels, it can be understood that the existing circumstances outlined above lead to serious implementation problems and challenges and erode the employee trust towards their elected and workplace leaderships. This lack of trust has serious negatives repercussion on employees' performance (Chiang \& Birtch, 2010, p. 129; Selden \& Sowa, 2011, p. 252).

\section{Stakeholders' attitude towards performance improvement approach}

The responses of both administrative and political leadership participants underlined a lack of positive attitude towards the performance improvement approach that has been used. This position was based on the belief of both sets of stakeholders that it is very difficult under the present circumstances in the municipality to set up clear goals and a workable strategy for a number of reasons such as the shrinking of the revenue base, the existing budgeting constraints and the organisational weaknesses.

The latter (organisational weaknesses) was more emphasised by the elected leadership that had a strong belief that the entity has been hampered by serious capacity gaps and weaknesses that do not allow serious implementation of the performance management initiatives to rectify the existing situation.

A number of employees, however, supported by the ward committee members believed that senior political and administrative managements have not been willing to take decisions supporting the majority of employees through serious performance improvement and development as well as planning and commitment to support its implementation.

These groups of participants, although agreeing that there were skills gaps within the organisational terrain of the municipality, indicated that many employees operating at all levels of the municipality had the qualifications, knowledge and skills sufficient for them to play a serious role in the planning and implementation of performance in the municipality.

The assessment of beliefs, attitudes, opinions and statements of key stakeholders in the municipality indicates that the trust among employees and the key stakeholders has been all but eroded and the subsequent present position vis-à-vis performance improvement approach is inimical to the majority of employees (DeNisi \& Pritchard, 2006, pp. 256-257; Judge, Thoresen, Bono, \& Patton, 2011, p. 377).

\section{Fairness of staff performance management and evaluation}

Within a municipality, the implementation of performance evaluation and management relies on technical, political, administrative and organisational factors (not necessarily in that order) (Selden, Ingraham, \& Jacobson, 2001, pp. 599-600).

This means that the leadership and management, both elected and administrative, need to act with honesty, fairness, transparency and integrity in such processes so that trust, motivation and job satisfaction among all employees are realised (DeNisi \& Pritchard, 2006, pp. 254-255; Mayer \& Gavin, 2005, p. 876).

Whilst both elected and administrative leaderships agreed that there was fairness in the process, the ward committee members and employees' representatives were adamant that such a review system is 'non-existent' because of the lack of 
leadership commitment, communication to all employees, transparency and integrity.

The latter responses and attitudes signify a deeply rooted lack of trust.

\section{Conclusion}

This article was based on a wider empirical study of a district municipality in the Eastern Cape and examined the relationship between trust and employee performance evaluation and management and its effect on service delivery. It is a subject that has not received sufficient attention in South African human resources literature.

The empirical dimension of the project was based on a literature review of existing literature of concepts and the country's relevant legislation as well as the case study method, a qualitative process that utilised a focus groups consisting of all municipal stakeholders as the key instrument of data collection.

The analysis of data showed conclusively an existence of problems and challenges facing the relationship among elected and administrative leaders. These are directly and indirectly related to power relationships and political factionalism, as well as employee capacity gaps, lack of active participation, information sharing and budget constraints.

Although it is evident that all stakeholders have identified the importance of job and performance evaluation, management and development as well as measures and targets, the opinions regarding sharing information, channels, planning and implementation were divided among stakeholders.

Employees and community-based participants were adamant that these elements of transparency, integrity, legality and collegiality are not met and the lack of commitment from leadership exacerbates the lack of trust among key stakeholders, especially employees and the wider community.

Mistrust in the process of performance evaluation management and improvement results in employee negativity and has negative consequences for service delivery.

\section{Acknowledgements}

This opinion paper is based partly on the author's dissertation 'A performance management model for supporting improved local government service delivery: A case study of the Joe Gqabi District Municipality'. The dissertation can be found at http://scholar.sun.ac.za/handle/10019.1/98102. The author acknowledges the contribution of the participants in the article.

\section{Competing interests}

The author declares that he has no financial or personal relationships that may have inappropriately influenced him in writing this article.

\section{Authors' contributions}

Z.J.N. was the sole investigator and author of this study.

\section{Funding information}

This research received no specific grant from any funding agency in the public, commercial or not-for-profit sectors.

\section{Data availability statement}

Data sharing is not applicable to this article as no new data were created or analysed in this study.

\section{Disclaimer}

The views and opinions expressed in this article are those of the author and do not necessarily reflect the official policy or position of any affiliated agency of the author.

\section{References}

Allan, G. (2003). A critique of using grounded theory as a research method. Journal of Business Research Methods, 2(1), 1-10.

Belle, N. (2014). Leading to make a difference: A field experiment on the performance effects of transformational leadership, perceived social impact, and public service motivation. Journal of Public Administration Research and Theory, 24(1), 109-136. https://doi.org/10.1093/jopart/mut033

Boerner, S., Eisenbeiss, S. A., \& Griesser, D. (2007). Follower behavior and organizational performance: The impact of transformational leaders. Organizational Studies, 13(3), 15-26. https://doi.org/10.1177/10717919070130030201

Bryman, A. (2011). Business research methods. Cambridge: Oxford University Press.

Caillier, J. G. (2014). Toward a better understanding of the relationship between transformational leadership, public service motivation, mission valence, and employee performance: A preliminary study. Public Personnel Management, 43(2), 218-239. https://doi.org/10.1177/0091026014528478

Cameron, R. (2007). Metropolitan government in South Africa: The limits of formal reorganisation. In J. P. Collin \& M. Robertson (Eds.) Governing metropolises: Profiles of issues and experiments on four continents, pp. 345-371. Quebec City: Presses del' Universite Laval.

Cameron, R (2010). Redefining political administration relationships in South Africa. International Review of Administrative Sciences, 76(4), 676-701.

Chiang, F., \& Birtch, T. (2010). Appraising performance across borders: An empirical examination of the purposes and practices of performance appraisal in a multicountry context. Journal of Management Studies, 47(7), 1365-1393. https://doi. org/10.1111/j.1467-6486.2010.00937.x

Cho, Y. J., \& Lee, J. W. (2011). Perceived trustworthiness of supervisors, employee satisfaction and cooperation. Public Management Review, 13(7), 941-965. https://doi.org/10.1080/14719037.2011.589610

Corbin, J., Strauss, A., \& Strauss, A. L. (2014). Basics of qualitative research. Los Angeles, CA: SAGE.

Creswell, J. W. (2013). Research design: Qualitative, quantitative, and mixed methods approaches (4th edn.). Los Angeles, CA: SAGE.

Den Hartog, D., Boselie, P., \& Paaiwe, J. (2004). Performance management: A model and research agenda. Applied Psychology: An International Review, 53(4), 556-560. https://doi.org/10.1111/j.1464-0597.2004.00188.x

DeNisi, A., \& Pritchard, R. (2006). Performance appraisal, performance management, and improving individual performance: A motivational framework. Management and Organization Review, 2(2), 253-277. https://doi.org/10.1111/j.1740-8784 2006.00042.x

Department of Cooperative Governance and Traditional Affairs. (2009). State of Local Government in South Africa: National State of Local Government Assessment. Working Document. Pretoria: Government Printers.

Department of Statistics South Africa. (2016). Community survey. Pretoria: Statistics South Africa.

Eastern Cape Socio Economic Council (ECSECC). (2017). Joe Gqabi District Municipality Socio-Economic Review and Outlook, April. East London: Eastern Cape Socio Economic Council.

Fernandez, S. (2008). Examining the effects of leadership behavior on employee perceptions of performance and job satisfaction. Public Performance and Management Review, 32(2), 175-205. https://doi.org/10.2753/PMR15309576320201

Gibson, C. M. (2006). Citizens at the center: A new approach to civic engagement Washington, DC. Retrieved from http://www.casefoundation.org/pressroom/ publications/citizens-at-the-center. 
Hall, D., Pilbeam, S., \& Corbridge, M. (2013). Contemporary themes in strategic people management. A case-based approach. Basingstoke: Palgrave Macmillan.

Harwell, M. R. (2011). Research design in qualitative/quantitative. In C. F. Conrad \& R. C. Serlin (Eds.), The SAGE handbook for research in education: Pursuing ideas as the keystone of exemplary inquiry, pp. 147-163. Los Angeles, CA: SAGE.

Hassan, S., \& Hatmaker, D. M. (2015). Leadership and performance of public employees: Effects of the quality and characteristics of manager-employee relationships. Journal of Public Administration Research and Theory, 25(4), 1127-1155. https://doi.org/10.1093/jopart/muu002

Hoijer, B. (2008). Ontological assumptions and generalisations in qualitative (audience) research. Europe Journal of Communication, 23(3), 275-294. https:// doi.org/10.1177/0267323108092536

Judge, T. A., Thoresen, C. J., Bono, J. E., \& Patton, G. K. (2001). The job satisfactionjob performance relationship: A qualitative and quantitative review. Psychological Bulletin, 127(3), 376-407. https://doi.org/10.1037/0033-2909.127.3.376

Mantzaris, E., \& Pillay, P. (2014). Navigating through the political/administrative corruption conundrum South African case studies. African Journal of Public Affairs, 7(2), 17-26.

Maxwell, J. A. (2010). Qualitative research design: An interactive approach (3rd edn.) Los Angeles, CA: SAGE.

Mayer, C. M., \& Gavin, M. B. (2005). Trust in management and performance: Who minds the shop while the employees watch the boss. Academy of Management Journal, 48(5), 874-888. https://doi.org/10.5465/amj.2005.18803928

Mopaki, O., \& Mutono, A. (2016). The balanced scorecard system as a performance measurement tool for public sector organisations: The case of the Media Information Communications Technology Sector Education Training Authority, Republic of South Africa. British Journal of Applied Science \& Technology, 8(1), 1-9. https://doi.org/10.9734/BJAST/2016/29531

National Public Commission. (2014). National development plan 2030 our future make it. Pretoria: Government Printers.

Ngamlana, N. (2011). Politics and administration: The blurred line [Online]. Retrieved from http://www.afesis.org.za/Local-Governance-politics-and-administration-theblurred-line.

Palys, T., \& Atchison, C. (2012). Qualitative research in the digital era: Obstacles and opportunities. International Journal of Qualitative Methods, 11(4), 352-367. https://doi.org/10.1177/160940691201100404

Rainey, H. G. (2014). Understanding and managing public organizations. San Francisco, CA: Jossey-Bass.

Republic of South Africa (RSA). (1996). Constitution of the Republic of South Africa. Pretoria: Government Printers.
Republic of South Africa (RSA). (1997). Water Services Act (Act 108 of 1997). Pretoria: Government Printers.

Republic of South Africa (RSA). (1998a). White Paper on Local Government, 1998. Pretoria: Government Printers.

Republic of South Africa (RSA). (1998b). Skills Development Act (Act 97 of 1998). Pretoria: Government Printers.

Republic of South Africa (RSA). (2000a). Local Government: Municipal Systems (Act 32 of 2000). Pretoria: Government Printers.

Republic of South Africa (RSA). (2000b). Local Government: Municipal Structures Amendment (Act 33 of 2000). Pretoria: Government Printers.

Republic of South Africa (RSA). (2001). Municipal planning and performance management regulations. 2001. Regulation No 7146 in Government notice R 796 in Government Gazette 22605. Pretoria: Government Printers.

Rome, G. R. (2015). Focus groups in qualitative research. Retrieved from http://www. qualitative-research.net/index.php/fqs/article/view/2087.

Schuler, R. S., \& Jackson, S. E. (2007). Strategic human resource management (2nd edn.). London: Blackwell Publishing Ltd.

Schultz, C., \& Van Der Walt, H. (2015). Reinventing HR. Randburg: Knowledge Resources.

Schwab, C. (2017). The global competitiveness report 2017-2018. Geneva: World Economic Forum.

Selden, S. C., Ingraham, P. W., \& Jacobson, W. (2001). Human resource practices in state government: Findings from a national survey. Public Administration Review, 61(5), 598-607. https://doi.org/10.1111/0033-3352.00130

Selden, S. C., \& Sowa, J. (2011). Performance management and appraisal in human service organizations: Management and staff perspectives. Public Personnel Management, 40(3), 251-264. https://doi.org/10.1177/009102601104000305

Van Wart, M. (2011). Dynamics of leadership in public service: Theory and practice. New York: Routledge.

Vermeeren, B., Kuipers, B., \& Steijn, B. (2013). Does leadership style make a Difference? Linking HRM, job satisfaction, and organizational performance. Review of Public Personnel Administration, 34(2), 174-195.

Warnich, S, Carrell, M. R. Elbert, N. F, \& Hatfield, R. D. (2015). South African human resource management: Theory \& practice (5th edn.). London: Cengage Learning.

Williams, J. J. (2006). Community participation: Lessons from post-apartheid South Africa. Journal of Policy Studies, 27(3), 197-216. https://doi.org/10.1177/ $0734371 \times 13510853$

Wright, B., \& Pandey, S. (2010). Transformational leadership in the public sector: Does structure matter? Journal of Public Administration Research and Theory, 20(1), 75-89. https://doi.org/10.1093/jopart/mup003 